F. KORTLANDT

\title{
THE FORMATION OF THE OLD PRUSSIAN PRESENT TENSE
}

The obvious limitations which the character of the Old Prussian texts imposes on our knowledge of the language have given rise to two lines of investigation. Some authors have interpreted the material chiefly on the basis of evidence from cognate languages (e. g., Bezzenberger, 1907, Trautmann, 1910, Schmalstieg, 1974), while others have tried to start from the forms as they appear in the available material (e. g., Van Wijk, 1918, Schmid, 1963, Levin, 1976). There can be no doubt that I subscribe to the second approach. The two lines of thought are complementary, however, and the difference between them must not be exaggerated. As long as one is willing to take both the texts and the comparative evidence seriously, agreement can often be reached. The main objection to faithful reliance on the comparative evidence is that it automatically leads to a bias in the direction of the cognate languages. The history of Indo-European scholarship can properly be described as a gradual shift away from the languages which served as the primary basis for the reconstruction of the proto-language (cf. Mayrhofer, 1983). Under these circumstances, it would be unwise to base oneself primarily on evidence from cognate languages in the interpretation of the Old Prussian material.

The main piece of evidence for the flexion class of an Old Prussian verb in the present tense is the vowel before the 1st pl. ending -mai. The Enchiridion contains the following lst pl. forms (cf. Van Wijk, 1918, 133ff):

(1) athematic forms in -mai: asmai 'sind', et-skimai 'auferstehen', per-èimai 'kommen', wirstmai 'werden'. The attested $2 \mathrm{nd}$ pl. forms of these verbs are astai $(4 \mathrm{x}$, asti $2 \mathrm{x}$ in contiguous lines, estei $1 \mathrm{x}$ ), wirstai;

(2) forms in -āmai, -ümai: waitiāmai 'reden', quoitämai 'wollen', läikumai 'halten', po-läikumai 'behalten', en-laikümai 'anhalten' (read -läiku-). The attested 2nd pl. forms of these verbs are quoitēti, imperative läikutei, en-läikuti;

(3) forms in -ê(i)mai: billèmai 'sagen', druwēmai 'glauben', seggèmai 'tun', stallëmai 'stehen', klausēmai 'hören', au-paickēmai 'abdringen', en-wackēmai 'anrufen', en-wackeimai 'id', waidleimai 'zaubern'. The attested $2 \mathrm{nd}$ pl. forms of these 
verbs are druwētei, seggêti, stallēti, imperative billittei, seggittei $(3 \mathrm{x}$, once used as an indicative, seggita $1 \mathrm{x}$, segijtei $1 \mathrm{x}$ used as an indicative), klausieiti;

(4) forms in -au(i)mai: dinkaumai 'danken', dinkauimai 'id', 2nd pl. imperative dinkauti (cf. rikauile 'herrschet');

(5) thematic forms in -ammai, -emmai: per-weckammai 'verachten', giwammai 'leben', giwemmai 'id', klantemmai 'fluchen', per-klantemmai 'verraten', paikemmai 'trügen', po-prestemmai 'fühlen', wertemmai 'schwören'. No $2 \mathrm{nd}$ pl. forms of these verbs are attested;

(6) forms in -imai. These forms belong to the following categories:

(a) optative turrilimai 'müssten';

(b) preterito-present waidimai 'wissen', 2nd pl. waiditi, athematic 2nd sg. waisei, waisse, infinitive waist;

(c) verbs in -ït: kìrdimai 'hören', mēntimai 'lügen', ep-mēntimai 'belügen', er-nertimai 'erzürnen', turrimai 'haben', 2nd pl. turriti, imperative kīrdeiti (cf. crixteiti 'taufet'), kirdijti (cf. laukijti 'suchet', milijti 'liebet'), infinitive kirdit, kirditwei, turit, turrit, turritwei;

(d) loan words: grìkimai 'sündigen', madlimai 'bitten', schlūsimai 'dienen', perschlüsimai 'verdienen', massimai 'mögen', au-schpāndimai 'abspannen', 2nd pl. schlüsiti, imperative madliti, 3rd person griki-si, madli, massi, optative musilai, infinitive madlit, madlit, madliton, madlitwei, schlüsitwei;

(e) simple verbs: galbimai 'helfen', girrimai 'loben', gunnimai 'treiben', immimai 'nehmen', en-immimai-sin 'annehmen', pìdimai 'bringen', pidimai 'id', ser-rīpimai 'erfahren', et-wērpimai 'vergeben', 2nd pl. immati, imperative immaiti, imaiti, ripaiti 'folget', po-wiērptei 'lasset', infinitive girtwei, guntwei, imt, pijst, et-wiērpt (1x, et-wierpt $1 \mathrm{x}$, etpwērpt $1 \mathrm{x})$, po-wiērpt

(f) nasal presents: au-gaunimai 'gewinnen', po-gaunimai 'empfangen', po-stānimai 'werden', er-sinnimai 'erkennen', po-sinnimai 'bekennen', 2nd pl. er-sinnati, infinitive po-gaüt, po-stāt, po-stätwei, er-sinnat, po-sinnat;

(g) forms in -innimai: bebinnimai 'spotten', brewinnimai 'fördern', mukinnimai 'lehren', prei-stattinnimai 'vorstellen', tickinnimai 'machen', teckinnimai 'id', 2nd pl. imperative -inaiti, -innaiti, -inneiti, -ineiti, infinitive -int.

It is clear from this list that the regular lst pl. ending -imai ousted other endings under conditions which remain to be specified. I claim that this ending has a threefold origin. In the following I shall not go into a discussion of the points which have been clarified by Van Wijk (1918).

The forms in $-\bar{e}(i) m a i$ can be compared with Lith. -ejame. W. P. Schmid distinguishes between the type seggit 'tun' and the type druwit 'glauben', but derives both seggëmai and druwèmai from *-ejjamai (1963, 16ff). I think that this is correct. The difference between the two singular paradigms will be discussed below. 
Van Wijk reads au-paickèmai as -emmai and identifies it with paikemmai. which is in my view incorrect: the difference can be compared with the one between enwacke $(i) m a i$ and per-weckammai. Both of these present tense formations are related to the infinitive wackitwei 'locken' (cf. giwit, giwammai, per-klantit, per-klan-

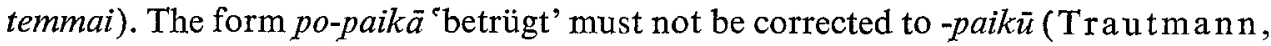
1910,405 ) but to -pāika (Van Wijk, 1918, 135), a view which is unjustly disregarded by Schmid (1963, 30).

As I have argued elsewhere (1974), we must assume final stress in the thematic forms in -ammai, -emmai: these verbs belong to the type with Balto-Slavic mobile accentuation (type $c$ of Stang, 1957). The accentual mobility is best preserved in giwit, giwammai, giwemmai, 2nd sg. giwassi (with final stress) and analogical giwasi, gïwu (with lst sg. ending, cf. Old Russian ̌̌ivu, Stang, 1957, 109), 3rd. sg. giwa. The retracted stress was generalized in the present tense of kirdìt 'hören' and laiküt 'halten', as is clear from lst pl. kïrdimai, läikumai. The 2nd pl. imperative forms kirdeiti and kirdijti represent different formations: the former contains the stem of the present tense and the ending of the PIE. optative, whereas the latter is derived from the stem of the infinitive (cf. Kortlandt, 1982, 7). The difference can be compared with the one between 2 nd sg. imperative dereis 'siehe' and en-diris 'siehe an'.

If the forms in $-\bar{e}(i) m a i$ and -au(i)mai can be derived from *ejjamai and *aujamai, it is reasonable to suppose that girrimai 'loben' continues *-jamai (cf. Van Wijk, 1918, 136, Schmid, 1963, 6). Unfortunately, the ja-flexion cannot be identified on the basis of the Old Prussian material alone, and it cannot be excluded that these verbs had joined another flexion class in prehistoric times. In any case we have to assume at least three different flexion types with a 1st pl. form in -imai which cannot be identified with the $j a$-flexion.

The verb waist 'wissen' has an athematic flexion in the singular, but the plural forms waidimai, waiditi differ from the athematic plural forms asmai, astai, wirstmai, wirstai. The obvious source of the linking vowel in this paradigm is the $3 \mathrm{rd}$ pl. ending *-int, which must be assumed for Balto-Slavic on the basis of the Slavic evidence (cf. Endzelin, 1944, 162). Since the athematic 1st and 2nd pl. forms were preserved in Slavic, the ending *-int must have been preserved in Prussian at a stage which was posterior to the separation between them.

The plural forms turrimai, turriti 'haben, sollen' resemble waidimai, waiditi, not druwēmai, druwētei or seggēmai, seggèti. Similarly, the 2 nd sg. form tur, which is found in the catechisms I and II, is quite unlike druwēse or seggēsei. In the Enchiridion we find the following forms:

1st sg. turri $1 \mathrm{x}$

2nd sg. turri $14 \mathrm{x}$, turei $6 \mathrm{x}$ 
3rd sg. turri $18 \mathrm{x}$, turei $8 \mathrm{x}$, turrei $1 \mathrm{x}$

1st pl. turrimai $20 \mathrm{x}$

2nd pl. turriti $3 \mathrm{x}$

3rd pl. turri $10 \mathrm{x}$, turei $1 \mathrm{x}$, ture $1 \mathrm{x}$

On the basis of these forms it seems probable to me that we have to start from a 3rd sg. form turei and a $3 \mathrm{rd} \mathrm{pl}$. form turri, the latter of which was in the process of being generalized in historical times. The motivation for this generalization can be found in the $j a$-flexion, where $-i$ is the expected $3 \mathrm{rd}$ person ending both in the singular and in the plural. The analogical introduction of $-e i$ in the $j a$-flexion is found in 3rd sg. et-wiêrpei 'vergibt' (infinitive et-wièrpt, 1st pl. et-wērpimai).

In this connection we may reconsider the paradigms of seggit and druwit in the Enchiridion. The following list does not contain the 2 nd pl. imperative forms of seggìt ( $5 \mathrm{x}$, twice used as an indicative).

1st sg. druwe $6 \mathrm{x}$, druwe $2 \mathrm{x}$, segge $1 \mathrm{x}$

2nd sg. druwē $3 \mathrm{x}$, druwēse $2 \mathrm{x}$, seggēsei $1 \mathrm{x}$

3rd sg. druwe $2 \mathrm{x}$, druwe $2 \mathrm{x}$, segē $1 \mathrm{x}$, segge $4 \mathrm{x}$

1st pl. druwēmai $1 \mathrm{x}$, seggēmai $2 \mathrm{x}$

2nd pl. druwētei $1 \mathrm{x}$, seggēti $1 \mathrm{x}$

3rd pl. druwē $1 \mathrm{x}$, segge $1 \mathrm{x}$, segge $2 \mathrm{x}$

I agree with Schmid (1963) that the paradigm of druwit reflects the eja-flexion, which was at least partly adopted by seggit. The form segge is ambiguous: it may represent either $-\bar{e}$ or $-e i$.

The other verbs which may belong to the same flexion class are even more difficult to interpret. The following forms of the verb billit 'sagen, sprechen' are attested in the Enchiridion:

1 st sg. billi $3 \mathrm{x}$, bille $1 \mathrm{x}$, preterit billai $1 \mathrm{x}$

2nd sg. blli $1 \mathrm{x}$ (read billi)

3rd sg. bille $4 \mathrm{x}$, bille $2 \mathrm{x}$, billi $2 \mathrm{x}$, billā $3 \mathrm{x}$, billa $1 \mathrm{x}$, preterit billa $4 \mathrm{x}$, billā-ts $4 \mathrm{x}$, bille $1 \mathrm{x}$

1st pl. billèmai $1 \mathrm{x}$

3rd pl. bille $2 \mathrm{x}$

In the other catechisms we find the $3 \mathrm{rd}$ sg. preterit forms I bela, bela-ts $2 \mathrm{x}$, II byla, byla-czt, bila-ts. I assume that billa is the regular preterit form, whereas the correct present tense form is bille. The 3rd sg. form billi translates the German subjunctive 'spreche' $(2 \mathrm{x})$ and appears to belong to the same paradigm as the $2 \mathrm{nd} \mathrm{pl}$. imperative form billitei. Thus, the present tense of this verb does not seem to differ from that of druwit outside the lst and 2nd sg. forms, which end in $-i$.

The attested forms of stallit 'stehen' are the following: 3rd sg. stallā $1 \mathrm{x}$, stalla $\vec{e} 1 \mathrm{x}$, stalle $1 \mathrm{x}$, stalle $2 \mathrm{x}$, stalli $1 \mathrm{x}$, per-stalle $1 \mathrm{x}$ 
1st pl. stallēmai $1 \mathrm{x}$

2nd pl. stallēti $1 \mathrm{x}$

3rd pl. stalle $1 \mathrm{x}$, stalle $1 \mathrm{x}$, per-stalle $1 \mathrm{x}$, per-stalle $1 \mathrm{x}$

Here again, I assume that stallā represents the preterit and stalle the regular present tense form.

We may now reconsider the following paradigm:

1st sg. quoi 'will' $3 \mathrm{x}$

2nd sg. quoi $2 \mathrm{x}, i-q u o i-t u 2 \mathrm{x}$

3rd sg. quoi $1 \mathrm{x}$, quoite $1 \mathrm{x}$, po-quoitē-ts $1 \mathrm{x}$

1st pl. quoitāmai $1 \mathrm{x}$

2nd pl. quoitēti $2 \mathrm{x}$

3rd pl. quoite $1 \mathrm{x}$, quoitā $1 \mathrm{x}$

The form quoita $\overline{\text { is }}$ found in the following context: Kadden Deiws wissan wargan prātin bhe quäitan lemlai bhe kümpinna quai noūmans stan emnan Deiwas niswintinai bhe swaian rīkin niquoitā daton perēit kāigi stwi ast stēisi pickullas stessei Switas bhe noūson kermeneniskan quäits schläit schpartina bhe poläiku mans drüktai en swaiäsmu wirdan bhe Druwien er prei noüson wangan sta ast swais Etneiwings labs quäits. „Wenn GOTT allen bösen Rath vnnd willen bricht vnd hindert so vns den Namen Gottes nicht heiligen vnd sein Reich nicht komen lassen wöllen Als da ist des Teuffels der Welt vnd vnsers fleisches wille Sondern stercket vnd behelt vns fest in seinem Wort vnd Glauben bisz an vnser ende das ist sein gnediger guter wille." I think that quoita is a preterit form used in the function of a subjunctive. The same can be maintained for the $1 \mathrm{st} \mathrm{pl}$. form quoitämai. The form quoitē represents the regular present tense indicative.

In conclusion, I regard the following forms as regular:

1st sg. turri, druwe, billi, quoi

2nd sg. turri, turei, druwe, druwēse, quoi

3rd sg. turri, turei, druwe, billēe, stallē, quoi, quoitēe, preterit billā, stallä

1st pl. turrimai druwēmai, seggèmai, billēmai, stallēmai, preterit quoitāmai

2nd pl. turriti, seggëti, stallêti, quoitēti

3rd pl. turri, druwē, seggè, billè, stallè, quoitè, preterit quoitā

For early Prussian I tentatively reconstruct the following paradigms on the basis of the comparative evidence (cf. Kortlandt, 1979):

\begin{tabular}{|c|c|c|c|c|}
\hline 1st sg. & *giriāa & ${ }^{*} \operatorname{tur}(e) i \bar{a}$ & *druwēiā & *esmā \\
\hline 2nd $\mathrm{sg}$. & ${ }^{*}$ girie $(s) i$ & ${ }^{*}$ turei $(s) e i$ & *druwēie $(s) i$ & *essei \\
\hline 3rd sg. & *girie & ${ }^{*}$ turei & *druwēie & *esti \\
\hline lst pl. & *giriama & *turima & *druwēiama & *esmai \\
\hline 2nd pl. & *giriete & *turite & *druwēiete & *estei \\
\hline $3 \mathrm{rd} \mathrm{pl.}$ & *giria & *turi & *druwẽia & $?$ \\
\hline
\end{tabular}


The paradigm of turit appears to reflect an extremely ancient flexion type which underlies the East Baltic and Slavic $i$-flexion.

The remaining verbal class with a 1st pl. ending -imai are nasal presents, which have a 2 nd pl. ending -ati. The verbs imt 'nehmen' and pijst 'tragen, bringen' appear to belong to the same class. Their flexion is exemplified by the following forms: 1st sg. imma $1 \mathrm{x}$, po-sinna $4 \mathrm{x}$

3rd sg. eb-immai 'begreift' $1 \mathrm{x}$, pìdai $1 \mathrm{x}$, po-stänai $6 \mathrm{x}$, en-gaunai $1 \mathrm{x}$, en-gaunei $1 \mathrm{x}$, po-gaunai $1 \mathrm{x}$, po-gauni $1 \mathrm{x}$

1st $\mathrm{pl}$. immimai $2 \mathrm{x}$, en-immimai-sin $1 \mathrm{x}$, pidimai $1 \mathrm{x}$, pidimai $1 \mathrm{x}$, er-sinnimai $1 \mathrm{x}$, posinnimai $1 \mathrm{x}$, po-stānimai $1 \mathrm{x}$, au-gaunimai $1 \mathrm{x}$, po-gaunimai $1 \mathrm{x}$

2nd pl. immati $1 \mathrm{x}$, er-sinnati $1 \mathrm{x}$

3rd pl. po-sinna $1 \mathrm{x}$, po-stānai $1 \mathrm{x}$, po-stanai $1 \mathrm{x}$, po-gäunai $1 \mathrm{x}$

This type is distinct from the aja-flexion:

3rd sg. peisai 'schreibt' $1 \mathrm{x}$

3rd pl. peisāi 1x, ettrāi ‘antworten’ 1x, kelsāi ‘lauten’ 1x, kaltzāa ‘id’ 1x

For early Prussian I tentatively reconstruct the following paradigm:

1st sg. *zinā

2nd sg. *zinā (se)i

3rd sg. *zinäi

1st pl. *zinima $<$ *ininma

2nd pl. *zinte $<*$ zinnte

3rd pl. * zina $<*$ zinna

The difference between the 1 st and 2 nd pl. forms must have arisen as a result of the different chronological order of syllabification and simplification of the respective consonant clusters. The $2 \mathrm{nd} \mathrm{pl}$. form was subsequently remodeled to *zinate on the basis of the $3 \mathrm{rd} \mathrm{pl}$. form. When final long diphthongs were shortened, stem-stressed thematic verbs apparently adopted the paradigm reconstructed here. The frequent ina-flexion may have been instrumental in this analogical development. The attested forms of this class are the following:

1st sg. -inna $2 \mathrm{x}$, -inai $1 \mathrm{x}$, -inne $1 \mathrm{x}$

2nd sg. -inai $1 \mathrm{x}$, -inei $1 \mathrm{x}$

3rd sg. -inna $9 \mathrm{x}$, -ina $4 \mathrm{x}$, -inno $1 \mathrm{x}$, -inai $4 \mathrm{x}$, -innei $1 \mathrm{x}$, -inne $1 \mathrm{x}$

1st pl. -innimai $6 \mathrm{x}$

3rd pl. -inna $3 \mathrm{x}$, -ina $2 \mathrm{x}$, -inai $1 \mathrm{x}$, -inne $1 \mathrm{x}$

As in the case of turei and turri, I think that we have to start from 3rd sg. -inai and 3rd pl. -inna, the latter form being generalized because it could be identified as the bare present tense stem with a zero ending. This generalization evidently did not reach the nasal presents of simple verbs. 
The analysis of the Old Prussian material presented here disposes of the identification of the $a / i$-alternation with the flexion of the Old Indic 9 th present class (e. g., Trautmann, 1910, 280, Van Wijk, 1918, 140), an identification which is incompatible with the laryngeal theory (cf. Stang, 1942, 145). It implies that the inaflexion, like the $i$-flexion, must have preserved the apophonic alternation in the early Prussian paradigm and that, consequently, the thematic ina-flexion of Lithuanian is an innovation. This is in accordance with the fact that the Latvian verbs in -inat are not thematic. There is no sufficient reason to assume that Latvian and Lithuanian have preserved different flexion types, as Stang proposes (1942, 182; 1966, 369). I rather assume that the 3 rd person ending -ina continues the singular in Latvian and the plural in Lithuanian, just as the characteristic vowel of the $i$-flexion stems from the singular in Slavic and from the plural in East Baltic. Indeed, the different generalization in the ina-flexion of Latvian and Lithuanian suggests that the difference between 3rd sg. and 3rd pl. forms was preserved in this flexion type at the time when the East Baltic dialects arose. In the thematic flexion, the difference had disappeared as a consequence of the neutralization between $e$ and $a$ after $j$ (cf. Kortlandt, 1979, 62f). The relation between the ina-flexion and nominal $n$-stems (Fraenkel, 1938) must be due to a secondary development.

In conclusion, it is probable that Prussian preserved an apophonic alternation between singular and plural forms both in the $i$-flexion and in nasal presents, an alternation which was lost in East Baltic and Slavic in prehistoric times. The reconstructed $i$-flexion offers a basis fro $m$ which both the East Baltic and the Slavic paradigms can be derived. The direct identification of the ina-flexion with nasal presents of roots in an obstruent allows the derivation of the Latvian and Lithuanian paradigms from a single flexion type. These considerations support the view that the Old Prussian texts are an imperfect representation of a remarkably archaic variety of Balto-Slavic.

\section{REFERENCES}

Bezzenberger A., 1907 - Studien über die Sprache des preussischen Enchiridions. $-\mathrm{KZ} 41,65-127$.

Endzelin J., 1944 - Altpreussische Grammatik. - Riga.

Fraenkel E., 1938 - Zur Herkunft der litauischen Verba auf -inti und der Adjektiva auf -intelis. - APh 7, 17-39.

Kortlandt F., 1974 - Old Prussian Accentuation. - KZ 88, p. 299-306.

Kortlandt F., 1979 - Toward a Reconstruction of the Balto-Slavic Verbal System. Lingua, vol. 49 , p. $51-70$.

Kortlandt F., 1982 - Innovations which Betray Archaisms. - Baltistica, vol. 18 (1), p. 4-9. 
Levin J. F., 1976 - Toward a Graphology of Old Prussian Monuments: The Enchiridion. - Baltistica, vol. 12(1), p. 9-24.

Mayrhofer M., 1983 - Sanskrit und die Sprachen Alteuropas: Zwei Jahrhunderte des Widerspiels von Entdeckungen und Irrtümern. - Göttingen.

Schmalstieg W. R., 1974 - An Old Prussian Grammar. - University Park.

Schmid W. P., 1963 - Studien zum baltischen und indogermanischen Verbum. - Wiesbaden.

Stang C. S., 1942 - Das slavische und baltische Verbum. - Oslo.

Stang C. S., 1957 - Slavonic Accentuation. - Oslo.

Stang C. S., 1966 - Vergleichende Grammatik der baltischen Sprachen. - Oslo.

Trautmann R., 1910 - Die altpreussischen Sprachdenkmäler. - Göttingen.

Van Wijk N., 1918 - Altpreussische Studien. - Haag.

\section{SMULKMENA LXIV}

Senosios Lietuvos kanceliarijoje vartotose svetimose kalbose, kaip žinoma, aptikta nemaža lietuviškų žodžių. Daugiausia jų prirankiojo $\mathrm{K}$. Jablonskis iš tekstų, rašytų kanceliarine slavų kalba ir lenkiškai ${ }^{1}$. Iš lotyniškų tekstų turime aikštèn iškeltą tik vieną kitą lituanizmą. Neseniai Vilniaus universiteto klasikinės filologijos katedros doc. B. Kazlauskas atkreipé šių eilučių autoriaus démesi $\dot{\mathfrak{t}}$ lietuvišką žodi kušlikas (kušlèkas?) 'silpnų akių, žlibas', vartojamą $1690 \mathrm{~m}$. Vilniaus jèzuitu išleistoje lotyniškoje knygelèje "Theatrum Perennantis Gloriae... Michaeli Dowmont Siesicki... Anno 1690 Vilnae. Typis Academicis Soc. Iesu “. Jos p. 31 (pažymètas $\mathrm{G}_{2}$ ), eil. 23 rašoma: Kuszliki...facta Ducis Mavortia promant 'kušlikai...karo vado žygius teiškelia', o eil. 28 - Kuszlicij sensere graves 'žiaurūs kušlikai pajuto'. Šio žodžio lietuviškumas nekelia abejonių, plg. kùšlas 'silpnų akių, žlibas', kušlỹs, kùšlius 'kas neprimato, spangys, žabalas', kùšlinti 'prisikišus žiūrèti, žabalinèti'. Panašus žodis (pakitusia reikšme) yra patekęs ir i baltarusių tarmes: кýmлa, кýmлы, кушлb'l, кушла́mbi 'nevalyvas, netvarkingas; gauruotas; nevykęs, silpnas”2. Lotyniško teksto kušlikui visiškai tikslaus atitikmens lietuvių kalbos akademinis žodynas nepateikia, tačiau jame yra kušlẽkas 'kas neprimato, aklys, spangys, žabalis'. Gal kušlikas perdirbta iš kušlẽkas?

Z. Zinkevičius

1 J a blon s k is K. Lietuviški žodžiai senosios Lietuvos raštinių kalboje. K., 1941.

- Слоўнік беларускіх гаворак поўночна-заходняй Беларусіl і яе пагранічча. Мінск, 1980. T. 2. C. 595. 